\title{
A Broader Look at The Role of Andragogy in Engineering Education
}

\section{Col. Richard Melnyk, United States Military Academy}

COL Rich Melnyk is an Army Aviator and Assistant Professor in the Department of Civil and Mechanical Engineering at the United States Military Academy, West Point. He developed and implemented the first course offering of Thermal-Fluid Systems I in 2005. He was an Instructor and Assistant Professor from 2004-2007 and returned to teaching in 2015. He has a PhD in Aerospace Engineering, a PE in Mechanical Engineering, an MBA in Technology Management and recently commanded a Battalion at Hunter Army Airfield, Savannah, Georgia.

\section{Lt. Col. Brian J. Novoselich, United States Military Academy}

Brian Novoselich is an active duty Army Lieutenant Colonel currently serving as an Assistant Professor in the Department of Civil and Mechanical Engineering at the United States Military Academy (West Point). He earned his Ph.D. in Engineering Education at Virginia Tech in 2016. He holds Master's and Bachelor's degrees in mechanical engineering from The University of Texas at Austin and West Point respectively. His research interests include capstone design teaching and assessment, undergraduate engineering student leadership development, and social network analysis. He is also a licensed professional engineer in the Commonwealth of Virginia.

\section{Dr. Gregory Martin Freisinger, United States Military Academy}

Greg Freisinger is an Assistant Professor of Mechanical Engineering at the United States Military Academy at West Point. He holds a Bachelor of Science degree from Georgia Institute of Technology, as well as a Master of Science and Doctor of Philosophy from The Ohio State University. Greg was an Army engineer officer prior to graduate school, with experience in combat and construction military engineering. His research is primarily focused on biomechanical factors associated with injury and performance. 


\title{
A Broader Look at The Role of Andragogy in Engineering Education
}

\author{
Abstract \\ The word pedagogy is commonly used to describe teaching techniques and practices; \\ however, the root of the word actually denotes 'leading' or teaching children. The assumptions \\ inherent in this description may be incompatible with the desired outcomes and goals in \\ undergraduate engineering education. This work builds on previous effort which explored \\ whether the term andragogy, translated as 'leading man' or the education of adults, is a more \\ appropriate term to achieve the outcomes of engineering educators and engineering societies. \\ The previous paper used a case study approach to explore documents related to mechanical \\ engineering and the guiding documents of one mechanical engineering program and its key \\ stakeholders. The work showed that there was a disconnect between the term pedagogy and the \\ attributes required of mechanical engineers and desired of graduates of the program, particularly \\ when it came to assumptions about the nature of the students. \\ The purpose of this paper is to expand upon the previous mechanical engineering- \\ centered single case study and determine the applicability of andragogical learner assumptions to \\ additional engineering disciplines and programs. This study examines the guiding literature of \\ various engineering disciplines for evidence to support an andragogical orientation toward \\ undergraduate students. In addition, the study examines strategic documents associated with \\ multiple engineering programs to explore whether the findings of the single case study could \\ transfer to other engineering program related contexts. Finally, the study steps beyond \\ engineering programs to examine emerging andragogical literature. This literature survey \\ provides engineering educators a glimpse into the next evolution of how an andragogical
}


approach to undergraduate learners may be applied to the engineering education enterprise and accommodate more than just older, more experienced learners.

\section{Introduction}

In a recent workshop on engineering education, the National Academy of Engineering (NAE) President defined engineers as people who "create solutions serving the welfare of humanity and the needs of society' $[1, \mathrm{pg} .10]$. The report also goes on to say that engineers need to be creative and "straddle uncertainty", while engineering education should be increasingly “self-paced, self-serviced, virtual, and on demand"[1, pg. 14]. The type of student that can thrive in this type of environment needs to be self-directed and play an active role in their own education. Conversely, this same report adds that one aspect of modern engineering education is to emphasize "pedagogy". Pedagogy, by definition, describes how educators teach children with an emphasis on teacher-led organization and activities, however it is frequently used as a catch all for effective teaching techniques.

In Knowles' seminal work on the topic, he discusses and then contrasts pedagogy with the term "andragogy"[2]. Andragogy refers to the education of adults and carries with it certain assumptions that guide the educator-student relationship, which differ from a pedagogical approach. Adding the term andragogy to the instructional design lexicon for engineering education may provide engineering educators with the language necessary to more accurately describe the lens through which they view the learners in their environment.

The purpose of this paper was to further investigate the assumptions underlying the andragogical approach and then explore several key documents related to engineering education and institutions. This paper expands on previous work that features a similar analysis that 
investigated documents related to the Mechanical Engineering program at XXXXXXXX to determine if they supported the use of the assumptions in andragogy. The authors mapped the documents to the underlying andragogical assumptions and recorded the relative strength of the relationship between the language in the document and the various assumptions. The goal of this thread of work is to help determine if a broader range of engineering education is currently illserved by focusing only on the term pedagogy and not examining the concepts that form the basis of an andragogical approach.

\section{Background}

\section{Review of Andragogy}

The intent of this paper is not to provide a comprehensive review of andragogy. The topic is extensive and was discussed in some detail on the prior work in this area by Melnyk and Novoselich [3]. As discussed in the previous section, the primary difference between the terms pedagogy and andragogy is the intended recipient of the educational practice. The difference between teaching children and adults is not only in the types of topics covered, but in the entire approach to education. The five primary differences between child and adult learners that Knowles elucidates are related to the very concept of the learner, the learner's prior experiences, the learner's readiness to learn, how they orient themselves to learning, and their motivation to learn [2]. All of these topics are discussed in more detail in the aforementioned paper by Melnyk and Novoselich, however for the purpose of this work, a brief explanation is provided. Andragogy assumes that a learner is independent enough to direct their own learning and can incorporate and leverage prior experiences in the educational experience. An andragogical 
learner demonstrates a readiness to learn, can put learning in perspective to an appropriate application or problem to solve, and is thus motivated to learn to apply that learning in practice.

When these assumptions are met, the approach to education changes from a teacher-led concept to one where the 'teacher' is more of a guide and advisor on the student's increasingly self-directed journey. The NAE report and other key documents on the future of engineering included in 
Table 1 below point to a critical need for engineers who have the ability to direct themselves, think critically, and solve problems in uncertain and complex situations [4][5][6]. It would seem only logical that institutions of higher learning would want their students to possess these qualities also. However, the overwhelmingly widespread use of the term pedagogy in engineering education and the corresponding literature, implies an environment where the learner is not self-directed and relies on the teacher for instruction. These two situations appear incompatible.

\section{Review of Previous Work}

In a previous study, Melnyk and Novoselich used a single case study methodology to conduct a comprehensive review of several documents that guide educational practices for their program, institution, and the mechanical engineering profession. The documents examined in this previous work are shown in 
Table 1. The purpose of this examination was to discover mandates within the guiding literature that would favor a teaching and learning approach advocated by andragogy. 
Table 1: Summary of Previous Documents Reviewed

\begin{tabular}{|l|l|}
\hline \multicolumn{1}{|c|}{ Document } & \multicolumn{1}{c|}{ Description } \\
\hline $\begin{array}{l}\text { ABET Criterion 3: Student } \\
\text { Outcomes }\end{array}$ & $\begin{array}{l}\text { ABET specified student outcomes (a-k) that prepare } \\
\text { graduates to attain the engineering program's } \\
\text { educational objectives. }\end{array}$ \\
\hline $\begin{array}{l}\text { National Academy of Engineering } \\
\text { (NAE) report from the Committee } \\
\text { on the Engineer of 2020 }\end{array}$ & $\begin{array}{l}\text { Multi-phase report on examining the requirements for } \\
\text { engineering education in the 21 }\end{array}$ \\
\hline $\begin{array}{l}\text { American Society for Mechanical } \\
\text { Engineering (ASME) Vision 2030 }\end{array}$ & $\begin{array}{l}\text { Report detailing the current status and long term outlook } \\
\text { for mechanical engineering and mechanical engineering } \\
\text { technology education. }\end{array}$ \\
\hline $\begin{array}{l}\text { National Research Council (NRC) } \\
\text { How People Learn }\end{array}$ & $\begin{array}{l}\text { Comprehensive research study report summarizing } \\
\text { current research in the learning sciences and actual } \\
\text { practice in the classroom. }\end{array}$ \\
\hline $\begin{array}{l}\text { Army Leader Development } \\
\text { Strategy }\end{array}$ & $\begin{array}{l}\text { The Army's comprehensive approach to developing } \\
\text { leaders for the security challenges of tomorrow. }\end{array}$ \\
\hline $\begin{array}{l}\text { West Point Leader Development } \\
\text { System (WPLDS) Handbook }\end{array}$ & $\begin{array}{l}\text { An institution level document that implements the } \\
\text { Army's Leader Development Strategy and defines } \\
\text { student outcomes which explain what a graduate must } \\
\text { Be, Know, and Do. }\end{array}$ \\
\hline $\begin{array}{l}\text { Educating Future Army Officer for } \\
\text { a Changing World (EFAOCW) }\end{array}$ & $\begin{array}{l}\text { An institution level operational concept for the academic } \\
\text { program of the West Point Leader Development System. }\end{array}$ \\
\hline $\begin{array}{l}\text { Department of Civil and } \\
\text { Mechanical Engineering Mission } \\
\text { and Vision Statements }\end{array}$ & $\begin{array}{l}\text { Department level statements that communicate the } \\
\text { organization's reason for being and explain the } \\
\text { organization's future aspirations. }\end{array}$ \\
\hline
\end{tabular}

The results of this previous study indicated an overarching desire to create graduates with an andragogical mindset. However the authors cautioned that undergraduate mechanical engineering students may lack some of the attributes which form the underlying assumptions of andragogical learning practices. Specifically, young undergraduate mechanical engineering students may be unable to visualize how their education applies to a future career and may lack the experiences or intrinsic motivation to be an andragogical learner. Correspondingly, Melnyk and Novoselich advocated a deliberate and steady increase in self-directed (andragogical) learning practices as students progress along their undergraduate engineering education pathway (Figure 1). 


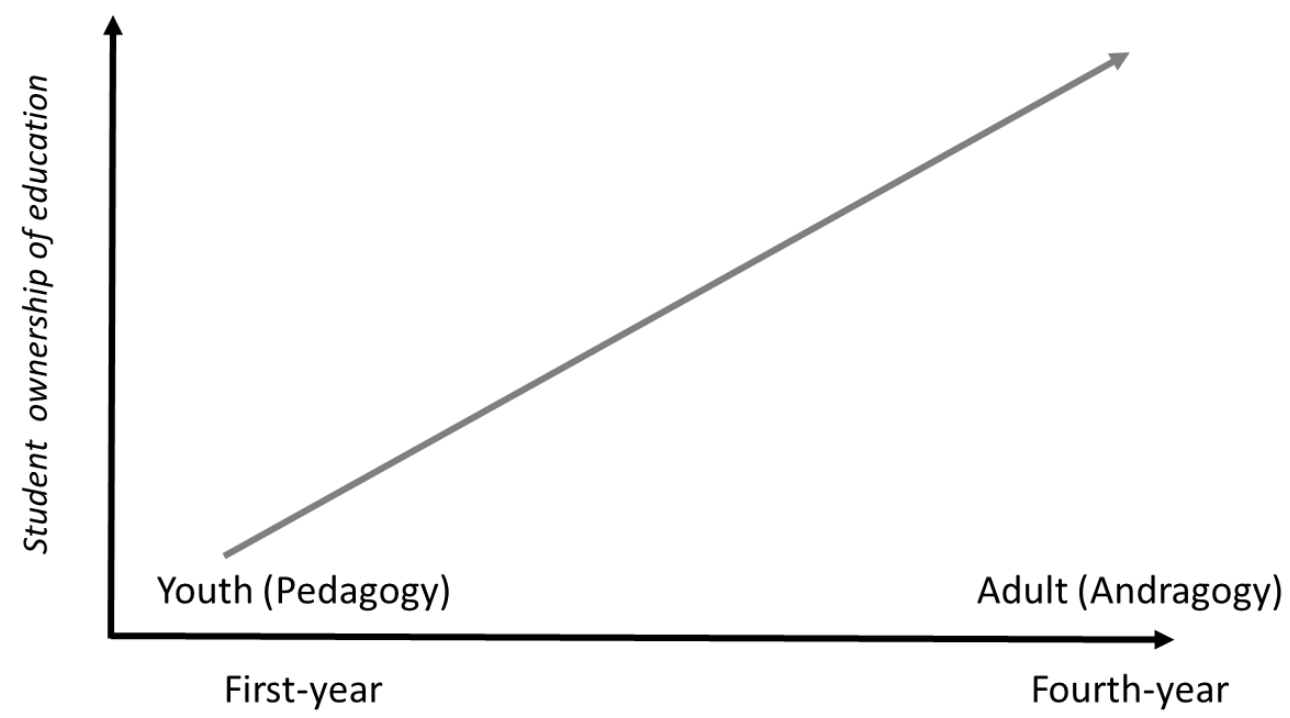

Figure 1: Student transition from youth to adult learning over four-year experience.

\section{Methods}

To provide a greater context for how andragogy may play a role in the larger enterprise of engineering education at their home institution, this study examined the disciplinary-specific guiding documents of other engineering disciplines operating on campus. The study also expanded beyond the single home institution completed previously by Melnyk and Novoselich, to examine the guiding documents of three additional well-respected engineering education institutions. These institutions were chosen because they provided open access to guiding, strategic documents similar to the one used in the previous paper by Melnyk and Novoselich that focused on a single institution. Unfortunately, many institutions do not make similar documents public, however anyone with interest could examine their internal document in the same way. All of the documents examined in this case study and a brief description are shown in Table 2 . 
Table 2: Summary of Documents Reviewed

\begin{tabular}{|l|l|}
\hline \multicolumn{1}{|c|}{ Document } & \multicolumn{1}{c|}{ Description } \\
\hline AICHE Body of Knowledge 2015 & $\begin{array}{l}\text { A Body of Knowledge that encompasses the range of } \\
\text { skills, knowledge, and abilities required of a chemical } \\
\text { engineer professional for the purpose of providing } \\
\text { guidance information to AIChE continuing education } \\
\text { efforts. }\end{array}$ \\
\hline $\begin{array}{l}\text { The Vision for Civil Engineering } \\
\text { in } 2025\end{array}$ & $\begin{array}{l}\text { An ASCE guiding document that articulates an } \\
\text { aspirational global vision for the future of civil } \\
\text { engineering addressing all levels and facets of the civil } \\
\text { engineering community. }\end{array}$ \\
\hline $\begin{array}{l}\text { Environmental Engineering Body } \\
\text { of Knowledge }\end{array}$ & $\begin{array}{l}\text { A Body of Knowledge which defines the knowledge, } \\
\text { skills and abilities needed to practice environmental } \\
\text { engineering at the professional level. }\end{array}$ \\
\hline $\begin{array}{l}\text { MIT Campaign Priorities for } \\
\text { Teaching and Learning }\end{array}$ & $\begin{array}{l}\text { Website Document that outlines priorities for the } \\
\text { Massachusetts Institute of Technology }\end{array}$ \\
\hline $\begin{array}{l}\text { Guiding the Future, a Strategic } \\
\text { Plan and Vision }\end{array}$ & $\begin{array}{l}\text { Current strategic plan for Georgia Institute of } \\
\text { Technology. }\end{array}$ \\
\hline Olin College Curricular Vision & $\begin{array}{l}\text { A guiding document for the development of Olin } \\
\text { College curriculum. }\end{array}$ \\
\hline
\end{tabular}

The purpose of this examination was to discover mandates within the documents that would favor an andragogical teaching and learning approach. Expanding the bounds of this study beyond a single engineering discipline and institution provides a richer context for the incorporation of andragogy into the greater field of engineering education. For the analyses, two of the authors individually coded each document for text related to the five andragogical assumptions. These instances were then evaluated to determine their degree of alignment with the assumptions. Documents that used language corresponding directly with the andragogical assumption were deemed directly applicable to that assumption (Table 3). For other passages within the text that did not used the direct language of the andragogical assumptions, the authors made subjective assessment of the underlying concept relayed in the text. As a part of the coding process, the authors negotiated instances of miss-alignment until 100\% agreement was 
established. Inter-rater reliability was not recorded as a part of the coding process, but is estimated at $80 \%$. The authors purposefully did not attempt to quantize the analyses because of the subjectivity inherent to the coding process. To add credibility to the process, the third author critically reviewed the work, consistent with the recommendations of the first two [7].

\section{Results and Discussion}

The authors chose documents from either other engineering disciplines or other institutions to examine for elements that would indicate goals corresponding to tenets outlined in andragogy. The documents in this paper were chosen based on availability, similarity to documents in the previous study, and applicability. In the first paper, the authors examined documents related to their own engineering discipline and from their institution. However, for this study similar documents were not always available or accessible for other institutions so the authors had to use documents that were accessible.

To develop their body of knowledge (BoK), the American Institute of Chemical Engineers surveyed academia and industry to determine what skills and knowledge chemical engineers required in various job roles and at different stages in their careers. While the document focuses on identifying technical skills that are outside the scope of this paper, it does discuss the need for chemical engineers to have knowledge and skills in the affective domain that relate to the assumptions in andragogy. In particular, the document highlights the need for chemical engineering students to be able to place their learning in context with the real-world problems they will solve. It also emphasizes students being motivated to become life-long learners. With regard to the concept of the learner, the document states that they should "show self-reliance when working independently”[7,pg. 21]. 
The American Society of Civil Engineering's vision of the Civil Engineer in 2025 discusses how the changing nature of the world shapes the role of engineering education and the attributes needed for a civil engineer. Not surprisingly, this document emphasizes the need for the learner to acquire and incorporate experience into their learning. Civil Engineering, as a discipline, is known for its emphasis on experience and professional licensure. In addition, this document discusses the need for civil engineers to also be life-long learners due to the rapidly changing nature of the discipline and the environment, again emphasizing the need for more intrinsic motivation to learn and grow [9].

The Environmental Engineering BoK acknowledges using the ASCE version of the same document to develop theirs. There are a lot of similarities between civil and environmental engineering so one would expect their BoK governing documents to be similar as well. As expected, environmental engineering emphasized the role of learner experiences in shaping the educational process. The BoK also stresses the motivation required to be a life-long learner, and the role of the student as self-directed and guiding their own education to attain the skills and knowledge required to be a competent environmental engineer [10].

In addition to the documents related to various engineering disciplines, the goal for this paper was to explore documents related to other engineering programs or colleges. These documents are slightly more difficult to obtain as open sources, so the analysis was limited to those institutions or programs that readily publish strategic or guiding documents.

The Massachusetts Institute of Technology outlines their campaign priorities in several areas to include the health of the planet, human health innovation and entrepreneurship, and teaching and learning. This last area is of concern for this study. The document explicitly uses the term 'pedagogical' while referring to "experiential learning" [11]. The website also 
discusses a seminar workshop where freshman students conduct a project that is linked to topics they will learn in other courses, a clear reference to andragogy's idea of students' orientation to learning. In fact, providing students with real-world research experience even at the undergraduate level is the concept behind MIT's Undergraduate Research Opportunities Program (UROP), started in 1969. Overall, several areas within the campaign priority section refer to aspects of andragogy.

The Georgia Institute of Technology's strategic vision and plan, a relatively short document, looks out to 2035 to help shape where the institution wants to go in that time. While the nature of the document does not discuss the role of the learner in general, it does detail a vision on the future curriculum. The plan recognizes the need for a very flexible curriculum to allow the learner to shape their own learning experience to the highest degree possible. This goal matches the concept of the self-directed learner in andragogy [12].

The Olin College Curricular Vision provided a roadmap for the Olin College faculty and administrators as they developed the curriculum for the emerging college. This document was a synthesis of curricular principles developed by the founding faculty, spurred by the Olin College strategic plan Invention 2000 [13]. This document specifies the vision, levels, and "Bold Goals" for the college curriculum. It focuses the faculty around two main elements for Olin students: 1) student curricular choices and 2) authentic engineering experiences across the four-year educational process. The overarching construct of the curriculum emerges, consisting of superb engineering built on a foundation of arts and entrepreneurship. The documents showed alignment in four of the five areas of andragogy. It is clear that the Olin faculty see their students as independent learners because the document specifies that all students will be empowered to pursue their unique educational goals through the development and proposal of a 
personal development plan. This unique facet of the Olin curriculum also relies heavily on the student being intrinsically motivated enough to develop and maintain their own self-development plan. The Olin curriculum emphasizes 'authentic' problem and project-based engineering experiences across the four years. These experiences culminate with a rigorous capstone design experience or "realization" phase of the curriculum in a student's senior year. Finally, the faculty are purposeful in the inclusion of arts and entrepreneurship within the curriculum to ensure the students have to tools necessary for success in a wide range of career goals, which provide relevance to the subjects taught.

Table 3: Results of Document Coding

\begin{tabular}{|l|l|l|l|l|l|}
\hline Document & $\begin{array}{c}1 \\
\text { Concept } \\
\text { of the } \\
\text { Learner }\end{array}$ & $\begin{array}{c}\mathbf{2} \\
\text { Role of } \\
\text { Learner } \\
\text { Experiences }\end{array}$ & $\begin{array}{c}\mathbf{3} \\
\text { Readiness } \\
\text { to Learn }\end{array}$ & $\begin{array}{c}\mathbf{4} \\
\text { Orientation } \\
\text { to Learning }\end{array}$ & $\begin{array}{c}\mathbf{5} \\
\text { Motivation }\end{array}$ \\
\hline $\begin{array}{l}\text { AICHE Body of } \\
\text { Knowledge 2015 }\end{array}$ & & & & & \\
\hline $\begin{array}{l}\text { The Vision for } \\
\text { Civil Engineering } \\
\text { in 2025 }\end{array}$ & & & & & \\
\hline $\begin{array}{l}\text { Environmental } \\
\text { Engineering } \\
\text { Body of } \\
\text { Knowledge }\end{array}$ & & & & & \\
\hline $\begin{array}{l}\text { MIT Campaign } \\
\text { Priority }\end{array}$ & & & & & \\
\hline $\begin{array}{l}\text { Guiding the } \\
\text { Future, a } \\
\text { Strategic Plan } \\
\text { and Vision }\end{array}$ & & & & \\
\hline $\begin{array}{l}\text { Olin College } \\
\text { Curricular Vision }\end{array}$ & & & & \\
\hline & & & & \\
\hline Directly Applicable & & & & \\
\hline
\end{tabular}




\section{Conclusions}

A review of the coding for multiple disciplines and the available engineering programs reveals some similarities and a slightly different pattern than in the previous paper. In both analyses, the governing documents reveal a high degree of applicability to the assumption related to the concept of the andragogical learner. This makes sense as many of these documents are aspirational in nature and express a desire for students who become engineer-leaders. It is also desired that students can think critically on their own and direct their own learning. Both studies also reveal a strong connection with the idea of the learner being intrinsically motivated. Again, this makes sense as the documents aim to portray students as wanting to make a difference in society and not simply studying engineering for monetary or other more personal reasons.

The one area that differed the most between the two studies was in the category of the role of the learner's experience. In this study, the documents showed a higher degree of applicability to that assumption. However, this fact was largely driven by the civil and environmental engineering documents. The environmental document admittedly borrowed heavily from the civil engineering discipline's body of knowledge documents so the two are confounded. Both disciplines emphasize practical experience and licensure because of both the large-scale nature of their work, and the high level of potential impact to the health and well-being of society.

What is clear from this and the previous analyses is that there remains a disconnect in nomenclature between that engineering societies and programs say they want in a student, and the use of the term pedagogy to describe how they plan to help educate those students. Engineering educators and societies want students who are self-directed, intrinsically motivated, can leverage real-world experience in their learning, and understand the broader context of what they are learning. However, the engineering education and educational literature, in general, still 
overwhelmingly uses the term pedagogy to describe their methods and practices of teaching.

This study and the one prior, are meant to increase awareness of the topic and help determine if the use of the term and underlying principles of andragogy have an important place in engineering education.

We advocate that engineering educators discuss the instructional design of their courses and programs with a more nuanced approach than currently exists. Adding the term andragogy into the engineering education lexicon may provide engineering educators the language necessary to describe a different set of assumptions about their learners. As we guide undergraduate engineering students along the path to professional practice and lifelong learning, pedagogy by itself fails to render the complexity of a learner centered environment that is responsive to the needs of the students.

\section{Considerations for Future Work}

There are two areas that require additional research and exploration to help make the term andragogy and the principles behind the theory more prominent in engineering education literature. This first area stems from a potential criticism of andragogy which is that students in undergraduate education simply do not meet the assumptions in the theory. For example, critics might say that students lack experiences relevant to the topic or lack internal motivation to learn. Therefore, additional research into the nature of undergraduate students should be done. Pembridge, et. al. conducted a study at Embry Riddle where he used a survey to determine students' perceptions of various attributes that he roughly mapped to the assumptions in andragogy [14]. This work can be expanded to other institutions to determine whether undergraduate students meet the assumptions of andragogy early in their education, warranting 
the implementation of andragogical principles. If not, researchers should determine the rate at which students may transition on the spectrum from 'child' to 'adult' learners.

The second major area of research may include the impact of incorporating andragogical principles in engineering education on meeting desired learning outcomes. In one of Knowles' last works on the subject, he discussed eight steps to implementing andragogy in practice [15]. These steps involve preparing the learner, creating the proper learning environment, involving learners in diagnosing their needs and developing appropriate objectives and plans, to name a few. Overall, these steps describe a much more collaborative learning model different from traditional teacher-centric instructional design at the undergraduate level. Where once a major is selected, many courses are prescribed and within those courses the objectives, syllabus, and assessment tools are determined solely by the professor and not in conjunction with the students. To determine the effectiveness of andragogy, studies on the effects of implementing collaborative course development may illuminate the utility of a paradigm shift. Understanding and potentially implementing andragogical practices may become even more crucial as one of Knowles' primary motivations for his theory, the acceleration of societal change, is becoming even more pronounced as we progress into the 21 st century. 


\section{References}

[1] Steve Olson, Engineering Societies and Undergraduate Engineering Education. Washington, D.C., 2017.

[2] M. Knowles, The Modern Practice of Adult Education. New York: Association Press, 1970.

[3] R. Melnyk and B. Novoselich, "The Role of Andragogy in Mechanical Engineering Education," in American Society of Engineering Education Conference and Exposition, 2017.

[4] NAE, "Educating the Engineer of 2020: Adapting Engineering Education to the New Century," Washington, D.C., 2005.

[5] ABET, "Criteria for Accrediting Engineering Programs," 2006.

[6] S. Danielson, A. Kirkpatrick, and E. Ervin, "ASME Vision 2030: Helping to Inform Mechanical Engineering Education," in Frontiers in Education Conference, 2011, p. T1J1.

[7] J. Creswell and D. Miller, "Determining Validity in Qualitative Inquiry," Theory Pract., vol. 39, no. 1, pp. 124-130, 2000.

[8] AICHE, "Body of Knowledge for Chemical Engineers," 2015.

[9] "The Vision for Civil Engineering in 2025 | ASCE." [Online]. Available: http://www.asce.org/vision2025/. [Accessed: 08-Oct-2017].

[10] S. W. Stinson, "Environmental Engineering Body of Knowledge," Educ. Theory, vol. 45, no. 1, pp. 43-54, 1995.

[11] MIT, "Teaching, Learning, and Living | The MIT Campaign for a Better World." [Online]. Available: https://betterworld.mit.edu/teaching-learning-and-living/. [Accessed: 29-Dec-2017].

[12] Georgia Institute of Technology, "Designing the future: a strategic vision and a plan," 2010.

[13] Olin College, "Olin College of Engineering Curricular Vision."

[14] J. Pembridge, "A Comparison of Adult Learning Characteristics between First-year and Senior Capstone Students," in 1s1st ASEE Annual Conference and Exposition, 2014.

[15] E. Holton, R. Swanson, and S. Naquin, "Andragogy in Practice: Clarifying the Andragogical Model of Adult Learning," Perform. Improv. Q., vol. 14, no. 1, pp. 118 $143,2001$. 